\title{
PENGARUH PRICE EARNING RATIO, PRICE TO BOOK VALUE, DAN INFLASI TERHADAP HARGA SAHAM YANG TERINDEKS IDX 30
}

\author{
Niki Nony Mutiarani, Riana R Dewi, Suhendro \\ Program Studi Akuntansi Fakultas Ekonomi Universitas Islam Batik Surakarta \\ Email: nikinonymutiarani@gmail.com
}

\begin{abstract}
This study aims to determine how the effect of Price Earning Ratio, Price to Book Value Ratio and Inflation on Indexed Stock Prices Idx 30 in the period 2016-2018. The object in the 20162018 research period was a company whose share price was IDX30 Teindeks on the Indonesia Stock Exchange. The population used in this study is 30 company shares and is based on a purposive sampling method that produces a sample of 11 companies. The dependent variable is represented by the stock price index, while the independent variables in this study are Price Earning Ratio, Price to Book Value Ratio and inflation. The research method used is a quantitative method that takes into account the company's market ratios of financial reports obtained from the IDX website and the level of inflation in Indonesia Partially the results of this study indicate that during the 2016-2018 period Price Earning Ratio, Price to Book Value Ratio and inflation do not affect IDX indexed stock prices 30.
\end{abstract}

Keywords: Stock Prices, Price Earning Ratio, Price To Book Value, Inflation

\section{PENDAHULUAN}

Pemerintah Indonesia semakin giat berupaya memperkenalkan saham kepada masyarakat. Hal ini terbukti dengan adanya campaign Yuk Nabung Saham (http://yuknabungsaham.idx.co.id) dengan program Sekolah Pasar Modal (http://sekolahpasarmodal.idx.co.id) yang diperkenalkan kepada Masyarakat. Pergerakan harga saham pada umumnya sebanding dengan kinerja suatu perusahaan, semakin baik kinerja perusahaan itu maka harga saham juga akan mengikuti. Investor yang tertarik pada kinerja perusahaan yang bagus maka akan meningkatkan demand atas saham suatu perusahaan ataupun sebaliknya. Menurut Putri, (2018) Harga pasar saham juga menunjukkan nilai dari perusahaan itu sendiri. Semakin tinggi nilai dari harga pasar saham suatu perusahaan, maka investor akan tertarik menjual sahamnya.

Untuk mengetahui kinerja perusahaan yang bagus, seorang investor dapat melihat aspek keuangannya. Ada berbagai macam rasio keuangan yang dapat digunakan investor dalam menilai harga saham di suatu perusahaan.Pada Penelitian ini Rasio keuangan yang akan digunakan adalah Rasio Pasar. Rasio ini berfokus pada hubungan harga saham dengan laba dan nilai buku per saham. Price to Earning Ratio dan Price to Book Value.

Price to Earning Ratio membandingkan harga saham di pasar dengan earning perusahaan, sehingga akan menunjukkan keyakinan investor terhadap besarnya earning yang akan di peroleh. Price Earning Ratio menunjukkan pertumbuhan laba dari perusahaan, dan investor akan tertarik terhadap pertumbuhan laba tersebut sehingga pada akhirnya akan pengaruh terhadap pergerakan harga saham. Menurut Dzulqodah \& Mujati, (2016) terdapat pengaruh positif signifikan Price Earning Ratio (PER) terhadap harga saham artinya semakin tinggi Price Earning Ratio (PER) maka harga saham semakin meningkat. Investor di Indonesia yang memilih perusahaan makanan dan minuman lebih berorientasi untuk mempertimbangkan Price Earning Ratio untuk menentukan keuntungan dalam berinvestasi.

Price to Book Value menunjukkan perbandingan harga saham terhadap nilai bukunya, sehingga dapat menampilkan ketidakwajaran harga saham. Apabila nilai Price to Book Value rendah 
menunjukkan bahwa harga saham tersebut murah, jika harga saham dibawah book value ada kecenderungan bahwa saham tersebut akan minimal sama dengan nilai bukunya. Sehingga saham tersebut berpotensi besar untuk naik dan dapat memberikan return yang tinggi.

Faktor lain yang menjadi pertimbangan investor dalam membeli saham di suatu perusahaan adalah tingkat inflasi di Indonesia. Tingkat Inflasi dapat menggambarkan kondisi ekonomi dimana terjadinya peningkatan harga produk-produk secara keseluruhan sehingga terjadi penurunan daya beli uang. Pernyataan tersebut menunjukkan bahwa penurunan inflasi merupakan sinyal baik bagi investor, karena seiring dengan menurunnya risiko daya beli uang dan risiko pendapatan riil Tandelilin, (2010). Menurut Y. I. Ningsih \& Muthmainnah, (2019) inflasi mempunyai pengaruh yang signifikan terhadap harga saham, namun menurut M. M. Ningsih \& Waspada, (2018) inflasi mempunyai pengaruh negatif terhadap harga saham.

Bursa Efek Indonesia mempunyai beberapa Indeks yang dapat dijadikan salah satu pertimbangan dalam pengambilan keputusan dalam berinvestasi. IDX30 adalah salah satu Indeks yang dimiliki oleh BEI yang dapat menjadi salah satu pertimbangan investor dalam memilih saham untuk berinvestasi. Indeks ini menunjukkan perusahan yang berkinerja bagus dan mempunyai likuitas serta kapitalisasi pasar yang besar akan masuk dalam IDX30.

Atas uraian diatas, peneliti akan melakukan penelitian dengan judul "PENGARUH PRICE EARNING RATIO, PRICE TO BOOK VALUE, DAN INFLASI TERHADAP HARGA SAHAM YANG TERINDEKS IDX 30".

\section{Rumusan Masalah}

1) Bagaimana pengaruh price earning ratio terhadap harga saham perusahaan yang terindeks IDX30?

2) Bagaimana pengaruh price to book value ratio terhadap harga saham perusahaan yang terindeks IDX30?

3) Bagaimana pengaruh inflasi terhadap harga saham perusahaan di Indonesia yang terindeks IDX30?

\section{KAJIAN TEORI}

a. Teori Signal (Signalling Theory)

Teori signal mengungkapkan bahwa perusahaan harus memberikan informasi mengenai laporan keuangan kepada pemilik saham perusahaan. Menurut Jogiyanto, (2014), sinyal yang diterima investor dari perusahaan adalah dari setiap informasi yang diumumkan oleh perusahaan. Informasi yang dimaksud dapat dilihat dari rasio keuangan yang ditampilkan dalam laporan tahunan yang disampaikan perusahaan ke Bursa Efek Indonesia.

b. Saham

Menurut Hadi, (2013) ,Saham adalah surat berharga yang dapat diperjualbelikan oleh individu ataupun lembar di pasar modal. Investor saham dapat memperoleh keuntungan berupa deviden dan capital gain, yaitu selisih harga jual beli saham di pasar modal. Saham merupakan hak kepemilikan dalam suatu perusahaan. Menurut Jogiyanto, (2014) saham terdiri dari 3 jenis yaitu Saham Biasa (Common Stock), Saham Preferen (Preffered Stock), dan Saham Treasuri (Treasury Stock). Saham yang di perdagangkan oleh Bursa Efek di Pasar Modal dan bisa di beli oleh masyarakat umum adalah Jenis Saham Biasa. Harga saham terbentuk atas kekuatan permintaan dan penawaran di Pasar Modal. Harga saham juga dapat menunjukkan nilai dari suatu perusahaan. Pada umumnya semakin tinggi harga saham suatu perusahaan sebanding dengan nilai perusahaannya. Apabila kemampuan perusahaan untuk menghasilkan laba meningkat, maka harga saham juga akan 
meningkat(Husnan, 2001). Harga saham yang meningkat mencerminkan nilai perusahaan yang baik bagi investor. (Suharli, 2003), menyatakan bahwa nilai pemegang saham akan meningkat yang ditandai dengan tingkat pengembalian investasi yang tinggi kepada pemegang saham.

Menurut Bursa Efek Indonesia, Indeksa Saham atau Indeks Harga Saham adalah ukuran statistik perubahan gerak harga dari kumpulan saham yang dipilih berdasarkan kriteria tertentu dan digunakan sebagai sarana dan tujuan tertentu. Bursa Efek Indonesia hingga saat ini memiliki 24 jenis indeks saham. Namun Bursa Efek Indonesia tidak bertanggaung jawab atas produk yang diterbitkan oleh investor yang menggunakan indeksindeks di bursa efek Indonesia sebagai acuan (benchmark). Indeks IDX30 merupakan Indeks yang menunjukkan performa harga dari 30 saham perusahaan yang memiliki likuiditas tinggi dan kapitalisasi pasar besar serta didukung oleh fundamental perusahaan yang baik.

c. Rasio Keuangan

Berdasarkan pendapat Amin, (2010), rasio merupakan perbandingan satu angka dengan angka lainnya sebagai suatu hubungan. Sedangkan menurut Hery, (2015), Rasio keuangan adalah alat hitung untuk mengukur kondisi keuangan dan kinerja suatu perusahaan menggunakan data yang di tampilkan pada laporan keuangan perusahaan.

Menurut Hery, (2016), secara umumnya ada 5 rasio keuangan yang sering digunakan untuk menilai kondisi dan kinerja keuangan perusahaan. Berikut ini adalah 5 rasio yang biasa digunakan yaitu :

a Rasio Likuiditas

b Rasio Solvabilitas

c Rasio Profitabilitas

d Rasio Aktivitas

e Rasio Pasar

Dalam penelitian ini Rasio yang akan digunakan adalah 2 Rasio Pasar, yaitu:

(1) Price to Earning Ratio(PER)

Menurut Anoraga et al (2006:59), Market price atau harga pasar adalah harga pada pasar riil, pada pasar yang sedang berlangsung atau jika pasar sudah ditutup, maka harga pasar adalah harga penutupannya (closing price). Pada dasarnya harga saham merupakan nilai saham di pasar atau yang biasa disebut dengan nilai pasar atau harga pasar yang berfluktuasi dari waktu ke waktu tergantung dari prospek perusahaan di masa yang akan datang. Perusahaan yang diharapkan tumbuh dengan tingkat pertumbuhan tinggi (yang berarti mempunyai prospek yang baik), biasanya mempunyai PER yang tinggi. Price to Earning Ratio dapat diukur dengan rumus :

$$
\text { PER }=\frac{\text { Market Price Per Share }}{\text { Earning Per Share }}
$$

Dimana :

PER = Price to Earning Ratio

Market Per Share = Harga Pasar Saham

Earning Per Share $=\quad$ Nilai Buku per Saham

(2) Price to Book Value (PBV)

Menurut Hery, (2016), Price to book value merupakan rasio yang menunjukan hasil perbandingan antara harga pasar per lembar saham dengan nilai buku per lembar saham. Seperti pada perhitungan tingkat PER, harga pasar per lembar 
saham adalah harga penutupan. Rasio ini digunakan untuk mengukur tingkat harga saham apakah overvalued atau undervalued, dimana dapat menjadi salah satu pertimbangan investasi jangka panjang atau pendek. Nilai PBV dapat dihitung dengan rumus berikut ini :

$P B V=\frac{\text { Market } \text { Per Share }}{\text { Book Value per Share }}$

Dimana :

PBV = Price Book Value

Market Per Share = Harga Pasar Saham

Book Value Per Share $=\quad$ Nilai Buku per Saham

Nilai buku per lembar saham dapat dihitung dengan cara membagi total ekuitas dengan jumlah saham yang beredar. (Jogiyanto, 2014)

Book Value Per Share dapat hitung dengan rumus berikut

BVPS $=\frac{\text { Total Ekuitas }}{\text { Jumlah Saham yang Beredar }}$

Dimana :

BVPS $($ Book Value Per Share $)=$ Nilai Buku per Saham

\section{(3)Inflasi}

Menurut (Sukirno, 2016) pengertian inflasi adalah suatu kondisi dimana terjadi kenaikan harga barang-barang yang bersifat umum dan terus-menerus. Menurut Fahmi, (2015), Inflasi memiliki pengaruh besar kepada para investor dalam berinvestasi. Para investor menginginkan adanya inflasi aktual atau inflasi yang diharapkan. Dalam hubungan ini, jika inflasi jauh lebih tinggi dari perolehan investasi maka investasi tersebut akan dibatalkan demikian pula sebaliknya. Jika inflasi semakin tinggi tanpa diimbangi oleh kenaikan suku bunga maka keuntungan investasi, terutama di pasar uang menjadi tidak menarik lagi sehingga dapat menyebabkan melemahnya nilai tukar. Secara spesifik inflasi dapat meningkatkan pendapatan dan biaya bagi perusahaan, yaitu jika peningkatan biaya produksi lebih tinggi dari peningkatan harga yang dapat dinikmati oleh perusahaan maka profitabilitas perusahaan akan turun.

\section{Kerangka Pemikiran}

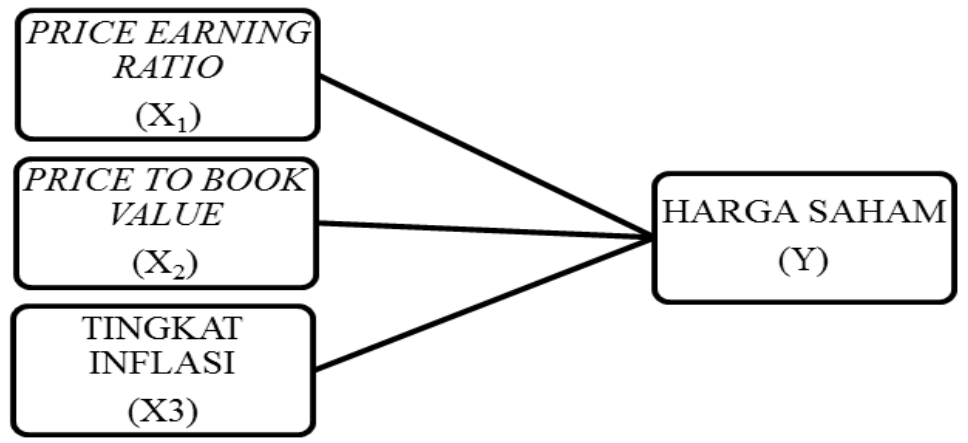

Gambar 1 Kerangka Berpikir

\section{Hipotesis}

H1 : Price to Earning Ratio berpengaruh terhadap harga saham perusahaan.

H2 : Price to Book Value berpengaruh terhadap harga saham perusahaan. 
H3 : Inflasi berpengaruh terhadap harga saham perusahaan.

\section{METODE PENELITIAN}

Penelitian ini adalah jenis penelitian kuantitatif yang menghasilkan kesimpulan secara deskriptif. Menurut (Sugiono, 2009) metode penelitian kuantitatif digunakan untuk meneliti pada populasi atau sampel tertentu. Teknik pengambilan sampel dilakukan secara random, pengumpulan data menggunakan instrument penelitian, analisis data bersifat kuantitatif atau statistik dengan tujuan untuk menguji hipotesis yang telah ditetapkan. Variabel dependen merupakan variabel yang menjadi tujuan utama untuk di teliti. Harga Saham adalah Variabel dependen pada penelitian ini. Variabel independen adalah variabel yang bersifat memberikan pengaruh terhadap variabel dependen. Variabel Independen pada penelitian ini yaitu Price earning Ratio, Price to Book Value dan Tingkat Inflasi Dalam melakukan penelitian ini peneliti menggunakan data sekunder yaitu berupa Laporan Keuangan Perusahaan yang terdaftar pada Indeks IDX30 dan data inflasi tahunan pada periode 2016-2018. Data sekunder peneliti peroleh dari Website Bursa Efek Indonesia dan Website Bank Indonesia. Harga Saham Perusahaan yang terindeks IDX30 pada periode tahun 2016-2018 merupakan populasi dalam penelitian ini. Sedangkan dalam pengambilan sampel penelitian, peneliti menggunakan teknik purposive sampling agar dapat merepresentasikan data yang lebih focus.

\section{Uji Asumsi Klasik}

Uji Normalitas

Dasar pengambilan keputusan memenuhi normalitas atau tidak adalah sebagai berikut (Ghozali, 2013)

1) Jika signifikansi kolmogorov smirrnov $<5 \%$ maka data tidak normal

2) Jika signifikansi kolmogorov smirnov $>5 \%$ maka data normal.

Tabel 1 Hasil Uji Normalitas - Kolmogorov Smirnov

\begin{tabular}{ccc}
\hline Probability & Std & Kesimpulan \\
\hline 0,120 & $>0,05$ & Normal \\
\hline
\end{tabular}

Berdasarkan tabel output SPSS tersebut, dapat diketahui bahwa nilai signifikasnsi Asiymp.sig (2-tailed) sebesar 0,120 lebih besar dari 0,05. Maka, dapat diasumsikan bahwa data berdistribusi normal. Dengan demikian, asumsi atau persyaratan normalitas dalam model regresi sudah terpenuhi.

\section{Uji Multikolineritas}

Uji Multikolineritas digunakan untuk menguji apakah model regresi ditemukan adanya korelasi antar variabel independen. Regresi yang baik akan menunjukkan tidak adanya korelasi antar variabel independen. Hal ini dapat diukur dari nilai VIF dari masingmasing variabel. Jika nilai toleransi $\leq 0,10$ atau VIF $\geq 10$ maka terdapat multikolinieritas, sehingga variabel tersebut tidak bisa digunakan.

Tabel 2 Hasil Uji Multikolinearitas

\begin{tabular}{lcr}
\hline Variabel & Tolerance & VIF \\
\hline $\operatorname{PER}\left(\mathrm{X}_{1}\right)$ & 0,805 & 1,234 \\
$\operatorname{PBV}\left(\mathrm{X}_{2}\right)$ & 0,801 & 1,249 \\
$\operatorname{NFLASI}\left(\mathrm{X}_{3}\right)$ & 0,990 & 1,010 \\
\hline
\end{tabular}


Berdasarkan hasil Uji Multikolinearitas pada tabel berikut nilai PER $\left(\mathrm{X}_{1}\right), P B V\left(\mathrm{X}_{2}\right)$ dan Inlfasi $\left(\mathrm{X}_{3}\right)$ dapat disimpulkan bahwa tidak ada multikolinieritas antar variabel independen dalam model regresi.

\section{Uji Autokorelasi}

Uji Autokorelasi bertujuan untuk menguji apakah ada korelasi antara kesalahan pengganggu pada periode t-1 (sebelumnya). Metode pengujian dilakukan dengan menggunakan uji Run Test dengan ketentuan jika nilai Asyimp.Sig (2-tailed) lebih besar dari 0,05 maka terdapat tidak terdapat gejala autokorelasi. Hasil Uji Autokorelasi disajikan dalam tabel sebagai berikut :

Tabel 3 Hasil Uji Autokorelasi

\begin{tabular}{ccc}
\hline Probability & Std & Kesimpulan \\
\hline 0,762 & $>0,05$ & Normal \\
\hline
\end{tabular}

Berdasarkan tabel diatas, diketahui nilai maka dapat disimpulkan tidak terdapat gejala atau masalah autokorelasi dalam model regresi.

\section{Uji Heteroskedatisitas}

Uji Heteroskedastisitas bertujuan untuk menguji apakah nila dalam model regresi terjadi ketidaksamaan variance residual satu pengamatan ke pengamatan yang lain. Uji Heteroskedastisitas dilakukan dengan melihat ada atau tidak nya pola tertentu pada grafik plot antara nilai prediksi variabel terikat yaitu ZPRED dengan residualnya SRESID. Hasil uji Heteroskedastisitas disajikan dalam gambar sebagai berikut:

Scatterplot

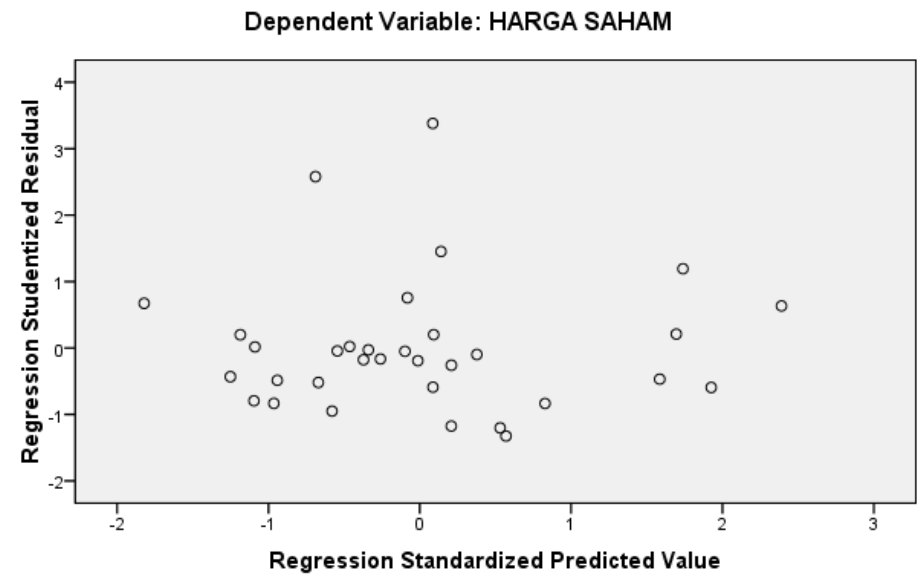

Gambar 2 Hasil Uji Heteroskesdatisitas

Berdasarkan gambar scatterplot pada gambar diatas dapat dilihat bahwa titik-titik menyebar secara acak diatas maupun dibawah angka 0 pada sumbu Y, maka dapat disimpulkan bahwa tidak terjadi heteroskedasititas pada model regresi, sehingga model regresi layak untuk memprediksi Harga Saham berdasarkan Variabel PER, PBV dan Tingkat Inflasi. 


\section{Analisis Regresi Berganda}

Penelitian ini menggunakan analisis regresi berganda.

Tabel 4 Hasil Analisis Regresi Berganda

\begin{tabular}{cccc}
\hline Variabel & Koefisien Regresi & $t_{\text {hitung }}$ & Sig \\
\hline Konstanta & 461,171 & & \\
PER $\left(X_{1}\right)$ & 164,737 & 1,162 & 0,255 \\
PBV $\left(X_{2}\right)$ & -1307.95 & $-1,1456$ & 0,156 \\
INFLASI $\left(X_{3}\right)$ & 273077,82 & 0,488 & 0.630 \\
\hline F $_{\text {hitung }}$ & 0,878 & & 0,464 \\
R Square & 0,289 & &
\end{tabular}

Berdasarkan hasil analisis regresi berganda pada tabel 6, maka diperoleh persamaan : $\mathrm{Y}=461,171+164,737 \mathrm{X}_{1}-1307,95 \mathrm{X}_{2}+273077,82 \mathrm{X}_{3}+\epsilon$

Dimana :

1) Konstanta (a) sebesar 461,171 menyatakan bahwa jika variabel PER, PBV dan Inflasi dianggap nol, maka Variabel Harga Saham 461,171.

2) Koefisien regresi PER $\left(\mathrm{X}_{1}\right)$ sebesar 67,21 menyatakan bahwa jika variabel PER mengalami kenaikan 1 satuan, sementara variabel PBV dan Inflasi dianggap konstan, maka akan menyebabkan kenaikan Harga Saham sebesar 164,737 satuan.

3) Koefisien regresi PBV $\left(\mathrm{X}_{1}\right)$ sebesar -1307,95 menyatakan bahwa jika variabel PBV mengalami kenaikan 1 satuan, sementara variabel PER dan Inflasi dianggap konstan, maka akan menyebabkan penurunan Harga Saham sebesar -1307,95 satuan.

4) Koefisien regresi Inflasi $\left(X_{3}\right)$ sebesar 273077,82 menyatakan bahwa jika variabel Inflasi mengalami kenaikan 1 satuan, sementara variabel PBV dan PER dianggap konstan, maka akan menyebabkan kenaikan Harga Saham sebesar 273077,82 satuan.

\section{Uji Kelayakan Model (Uji F)}

Uji F digunakan untuk menguji kelayakan model probabilitas $\mathrm{F}<$ maka taraf signifikan 0,05, maka dapa disimpulkan bahwa variabel independen secara bersama-sama berpengaruh signifikan terhadap variabel dependen. Perhitungan ini didasarkan pada hasil dari tabel ANOVA sebagai berikut :

Tabel 5 Hasil Uji Kelayakan Model

\begin{tabular}{ccc}
\hline Probability & Std & Kesimpulan \\
\hline 0,878 & $>0,05$ & Model Regresi Layak \\
\hline
\end{tabular}

\section{Uji Hipotesis (Uji t)}

Uji t digunakan untuk mengetahui signifikasi antar variabel independen dengan variabel dependen. Hasil dari uji t dapat dilihat pada tabel coefficient pada kolom significance. Jika probabilitas nilai $\mathrm{t}_{\text {hitung }}>\mathrm{t}$ tabel atau signifikansi $<0,05$ maka dapat dikatakan terdapat pengaruh signifikan antara variabel independen terhadap variabel dependen, maka Ho ditolak. Tetapi jika probabilitas nilai $t_{\text {hitung }}<\mathrm{t}_{\text {tabel }}$ atau signifikansi $>0,05$, maka dapat dikatakan tidak terdapat pengaruh yang signifikan antara variabel independen dengan variabel dependen, maka Ho diterima. Hasil pengujian uji t disajikan dalam tabel sebagai berikut:

Tabel 6 Hasil Uji Hipotesis (Uji t)

\begin{tabular}{llcl}
\hline riabel & tatistic & sbability & simpulan \\
\hline $\mathrm{R}\left(\mathrm{X}_{1}\right)$ & 62 & 0,255 & tolak \\
$\mathrm{V}\left(\mathrm{X}_{2}\right)$ & 456 & 0,156 & tolak \\
FLASI $\left(\mathrm{X}_{3}\right)$ & .88 & 0,630 & tolak \\
\hline
\end{tabular}




\section{Uji Koefisiensi Determinasi $\left(\mathbf{R}^{2}\right)$}

Untuk mengukur seberapa besar peranan variabel independen secara bersama-sama menjelaskan perubahan yang terjadi pada variabel dependen. Nilai koefisien determinasi berkisar diantara 0 sampai dengan 1, apabila nilai koefisien determinasi semakin mendekati 1, maka model tersebut semakin baik. Hasil pengujian koefisien determinasi disajikan dalam tabel sebagai berikut:

\section{Tabel 7 Hasil Uji Koefisien Determinasi}

\begin{tabular}{cc}
\hline iquare & simpulan \\
\hline 0,083 & $\begin{array}{c}\text { Berpengaruh 8,3\%, 91,7\% } \\
\text { dipengaruhi variabel lain }\end{array}$ \\
\hline
\end{tabular}

Berdasarkan hasil perhitungan koefisien determinasi pada tabel diatas, dapat diketahui bahwa koefisien determinasi $R$ square memiliki nilai sebesar $0,083=8,3 \%$, sehinggga dapat dinyatakan bahwa kemampuan variabel independen dalam mempengaruhi variabel dependen sebesar 8,3\% dan sisanya sebesar 91,7\% dipegaruhi oleh variabel-variabel lain diluar penelitian ini.

\section{PEMBAHASAN HASIL}

1) Pengaruh Price Earning Ratio Terhadap Harga Saham

Berdasarkan hasil penelitian dapat dilihat bahwa PER tidak berpengaruh terhadap harga saham. Artinya Penelitian ini mengindikasikan bahwa Price Earning Ratio yang tinggi tidak berarti perusahaan mempunyai kinerja yang bagus untuk investasi. Pada perhitungan rasio ini seorang investor juga akan melihat Earning Per Share dari suatu perusahaan, sehingga Investor akan mengetahui berapa besar Earning yang dihasilkan atas lembar saham yang dimiliki investor. Nilai rasio ini bukan menjadi faktor utama dalam penentuan keputusan Investasi. Seorang Investor akan melakukan pengamatan lebih terhadap fundamental perusahaan selain menggunakan variabel PER.

Hasil penelitian ini sejalan dengan penelitian yang dilakukan oleh Suhadak \& Siti, (2016), Amaliyah et al (2017) dan Priliyastuti \& Stella, (2017), dimana PER tidak mempunyai pengaruh yang signifikan terhadap Harga Saham. Berbeda dengan penelitian yang dilakukan oleh Tambunan, (2015), Dzulqodah \& Mujati, (2016),dan Desiana \& Lidia, (2017) yang menunjukkan adanya pengaruh positif signifikan Price Earning Ratio (PER) terhadap harga saham.

2) Pengaruh Price to Book Value Ratio Terhadap Harga Saham

Berdasarkan hasil penelitian dapat dilihat bahwa PBV tidak berpengaruh terhadap harga saham. Artinya perusahaan yang mempunyai kenaikan nilai price book value (PBV) tidak akan mempunyai pengaruh yang signifikan dalam pembentukkan harga saham. Karena pada dasarnya Harga Saham terbentuk karena adanya permintaan dan penawaran. Suatu perusahaan yang memiliki PBV yang tinggi tidak menjamin harga saham perusahaan tersebut naik Minat Investor dalam melakukan investasi tidak hanya melihat suatu perusahaan yang memiliki nilai PBV rendah. Tetapi Innvestor akan melihat apakah kinerja keuangan suatu perusahan itu bagus dan going concern. Rasio ini tepat jika digunakan untuk menilai suatu perusahaan yang nilai aset tetap nya besar, namun kurang tepat apabila digunakan dalam menilai perusahan yang nilai aset tetap nya lebh kecil daripada aset tidak berwujudnya. Karena perhitungan Nilai Buku suatu perusahaan adalah selisih dari Total Aset 
dengan Aset tidak berwujud dan kewajiban perusahaan. Ini artinya jika suatu perusahaan mempunyai nilai kwajiban yang lebih besar dibandingkan dengan total aset nya maka akan menurunkan nilai buku suatu perusahaan.

Hasil penelitian ini sejalan dengan penelitian Amaliyah et al (2017), Desiana \& Lidia, (2017) dan Putri, (2018), tetapi tidak sejalan dengan penelitian yang dilakukan oleh Cahyaningrum \& Antikasari, (2017) dimana price to book value parsial mempunyai pengaruh signifikan positif terhadap harga saham.

3) Pengaruh Tingkat Inflasi Terhadap Harga Saham

Berdasarkan hasil penelitian dapat dilihat bahwa Inflasi tidak berpengaruh terhadap harga saham Artinya perubahan tingkat inflasi pada periode tahun 2016-2018 tidak memberikan pengaruh secara signifikan. Tingkat inflasi pada periode tahun tersebut juga cenderung stabil di angka 3,5\%. Angka inflasi yang stabil tidak mempunyai pengaruh yang signifikan terhadap harga saham karena tidak menjadi pengaruh utama seorang investor melakukan penawarn atau permintaan suatu saham. Namun Jika inflasi semakin tinggi tanpa diimbangi oleh kenaikan suku bunga maka keuntungan investasi, terutama di pasar uang menjadi tidak menarik lagi sehingga dapat menyebabkan melemahnya nilai tukar.

Penelitian ini tidak sejalan dengan penelitian yang pernah dilakukan oleh Sepang, et al, (2015) Tambunan, (2015), Shabrina et al, (2016) dan Lutfiana, (2017), dimana hasilnya Inflasi secara parsial berpengaruh terhadap perubahan harga saham. Bagi investor yang akan berinvestasi pada perusahaan asuransi agar memperhatikan tingkat inflasi, sebagai acuan untuk menilai kelayakan investasi. tetapi sejalan dengan penelitian Rumengan, et al, (2015), Pardede, Hidayat, \& Sulasmiyati, (2016) Akbar et al ( 2017), Kennedy \& Hayrani, (2018), Mawarni, \& Widiasmara, (2018).

\section{KESIMPULAN}

1) Price earning ratio tidak berpengaruh terhadap harga saham perusahaan yang terindeks IDX30?

2) Price to book value ratio tidak berpengaruh terhadap harga saham perusahaan yang eks IDX30?

3) Inflasi tidak berpengaruh terhadap harga saham perusahaan di Indonesia yang terindeks IDX30?

\section{SARAN}

1) Bagi peneliti selanjutnya yang ingin melakukan penelitian lebih lanjut sebaiknya menggunakan sampel yang lebih banyak.

2) Bagi peneliti selanjutnya yang ingin melakukan penelitian lebih lanjut sebaiknya menggunakan periode yang lebih lama

3) Bagi peneliti selanjutnya yang ingin melakukan penelitian lebih lanjut yang berhubungan dengan harga saham diharapkan variabel yang mempengaruhi harga saham seperti Rasio Aktvitas, Rasio Likuiditas, dan variabel-variabel lain yang dapat mempengaruhi harga saham. 


\section{DAFTAR PUSTAKA}

Akbar, A. J., Yuliana, S., \& Marwa, T. (2017). Pengaruh Nilai Tukar, Suku Bunga dan Inflasi Terhadap Indeks Harga Saham Gabungan Di Bursa Efek Indonesia. E-Jurnal Manajemen Universitas Udayana, Vol 6 No 8.

Amaliyah, N. F., Priantono, S., \& Perwitasari, D. (2017). Pengaruh Earning Per Share (EPS), Price Earning Ratio (PER), Price To Book Value (PBV), Dan Debt To Equity Ratio (DER) Terhadap Harga Saham Pada Perusahaan Indeks Saham Syariah Indonesia (ISSI). JURNAL ECOBUSS, Vol 5 No 2.

Amin, W. T. (2010). Pokok-Pokok Analisis Laporan, Keuangan. Harvarindo.

Cahyaningrum, Y. W., \& Antikasari, T. W. (2017). Pengaruh Earning Per Share, Price To Book Value, Return On Asset, Dan Return On Equity Terhadap Perubahan Harga Saham Sektor Keuangan Tahun 2010-2014. JURNAL Economia, Vol 13 No 2.

Desiana, \& Lidia. (2017). Pengaruh Price Earning Ratio (Per), Earning Per Share (EPS), Devidend Yield Ratio (DYR), Dividend Payout Ratio (DPR), Book Value Per Share (BVS) Dan Price Book Value(PBV ) Terhadap Harga Saham Pada Perusahaan Subsektor Makanan Dan Minuman Yang Terdaftar Di JII. I-Finance Journal, Vol 3 No 2.

Dzulqodah, M., \& Mujati, Y. (2016). Pengaruh Earning Per Share Dan Price Earning Ratio Terhadap Debt To Equity Ratio Dan Harga Saham Pada Perusahaan Sektor Makanan Dan Minuman Di Bursa Efek Indonesia. Jurnal EKSIS,Vol XI No 1.

Fahmi, I. (2015). Fahmi, Irham. 2015. Manajemen Investasi. Edisi Kedua. Jakarta: Salemba Empat. Jakarta: Salemba Empat.

Ghozali, I. (2013). Aplikasi Analisis Multivariate dengan Program SPSS (ketujuh, Vol. 5). Semarang: Badan penerbit Universitas Diponegoro.

Gitman, L. J. (2015). Principles of Management Finance 12th Edition. Boston: Pearson Education, Inc.

Hadi, N. (2013). Pasar Modal: Acuan Teoritis dan Praktis Investasi di Instrumen Keuangan Pasar Modal. Yogyakarta: Graha Ilmu.

Hery. (2015). Analisis Laporan Keuangan. Edisi 1. Yogyakarta: Center For Academic Publishing Services.

Hery. (2016). Analisis Laporan Keuangan. Jakarta: Grasindo.

Husnan, S. (2001). Dasar-Dasar Teori Portofolio Dan Analisis Sekuritas. Yogyakarta: AMP YPKN.

Jogiyanto. (2014). Teori Portofolio dan Analisis Investasi (Edisi ke 10). Yogyakarta: BPFE.

Kennedy, P. S. J., \& Hayrani, R. (2018). Pengaruh Faktor-Faktor Ekonomi Makro : Inflasi, Kurs, Harga Minyak, Dan Harga Bahan Bangunan Terhadap Harga Saham Perusahaan Properti Di BEI. Jurnal Mitra Manajemen, Vol 2 No 4.

Lutfiana, I. M. (2017). Kontribusi Inflasi, Suku Bunga, Kurs, Produk Domestik Bruto Terhadap Harga Saham Kelompok Jakarta Islamic Index Di Indonesia Periode 20072015. An-Nisbah: Jurnal Ekonomi Syariah, Vol 4 No 1.

Mawarni, C. P. \& Widiasmara, A. (2018). Pengaruh FED Rate, Harga Minyak Dunia, BI Rate, Inflasi Dan Kurs Rupiah Terhadap Indeks Saham Syariah Indonesia (ISSI) Periode Tahun 2011-2017. Jurnal Inventory, Vol 2 No 2.

Ningsih, M. M., \& Waspada, I. (2018). Pengaruh Bi Rate Dan Inflasi Terhadap Indeks Harga Saham Gabungan (Studi Pada Indeks Properti, Real Estate, Dan Building Construction, di BEI Periode 2013 - 2017). Jurnal MANAJERIAL, Vol 17 No 2

Ningsih, Y. I., \& Muthmainnah, M. (2019). Pengaruh Inflasi, Kurs, Suku Bunga, dan Harga Minyak Dunia Terhadap Indeks Harga Saham Industri Pertambangan di Bursa Efek 
Indonesia Periode 2012-2015. Ekonomis: Journal of Economics and Business, Vol 3 No 1.

Pardede, N., Hidayat, R. R., \& Sulasmiyati, S. (2016). Pengaruh Harga Minyak Mentah Dunia, Inflasi, Suku Bunga (Central Bank Rate), dan Nilai Tukar (Kurs) Terhadap Indeks Harga Saham. Jurnal Administrasi Bisnis (JAB), Vol 39 No 1

Priliyastuti, N., \& Stella. (2017). Pengaruh Current Ratio, Debt To Asset, Debt To Equity, Return on Assets Dan Price Earnings Ratio Terhadap Harga Saham. Widyakala, Vol 3 No 1.

Putri, H. T. (2018). Pengaruh Earning Per Share (Eps) Dan Price Book Value (Pbv) Terhadap Harga Saham Pada Industri Retail Yang Terdaftar Di Bei Periode 20132016. J-MAS (Jurnal Manajemen Dan Sains), Vol 3 No 2

Rumengan, Andre Wellan Tommy, Parengkuan Taroreh, R. (2015). Tingkat Inflasi, Suku Bunga, Earning Pershare, Dan Devidend Payout Ratio Pengaruhnya Terhadap Harga Saham Perusahaan Telekomunikasi Yang Go Public Di Bursa Efek Indonesia. Jurnal Riset Ekonomi, Manajemen, Bisnis Dan Akuntansi, Vol 3 No 3.

Sepang, V. V., K, P. S. J., \& Sihombing, S. (2015). Pengaruh Pertumbuhan Laba Dan Inflasi Terhadap Harga Saham Perusahaan Asuransi Di. Jurnal Ilmiah Buletin Ekonomi, Vol 19 No 2.

Shabrina, S., Ruliana, T. R., \& Dewi, C. K. (2016). Pengaruh Bi Rate, Inflasi Dan Kurs Terhadap Harga Saham Perusahaan Perbankan Bumn Yang Terdaftar Di Bursa Efek Indonesia Periode 2012-2016.Jurnal Ekonomia Vol 7 No 14.

Sugiono, A. (2009). Panduan Praktis Dasar Analisa Laporan Keuangan. Jakarta.: PT. Grasindo.

Suhadak, M. B. B., \& Siti Ragil Handayani. (2016). Pengaruh Earning Per Share (EPS), Return On Equity (ROE), Dan Price Earning Ratio (PER) Terhadap Harga Saham (Studi Pada Perusahaan Telekomunikasi Yang Terdaftar di Bursa Efek Indonesia Periode Tahun 2010-2014). Jurnal Administrasi Bisnis, Vol 41 No1

Suharli, M. (2003). Studi Empiris Mengenai Pengaruh Profitabilitas,Leverage, Dan Harga Saham Terhadap Jumlah Deviden Yang Diterima.

Sukirno, S. (2016). Makroekonomi: Teori Pengantar (Ketiga). Jakarta: PT Raja Grafindo Persada.

Tambunan, B. H. (2015). Pengaruh Price Earning Ratio, Tingkat Suku Bunga, Dan Tingkat Inflasi Terhadap Harga Saham. Jurnal Akuntansi dan Bisnis, Vol 1 No 2.

Tandelilin. (2010). Portofolio dan Investasi: Teori dan Aplikasi (Pertama). Yogyakarta: Kanisius. 